\title{
Prognostic value of CD8 + PD-1+ immune infiltrates and PDCD1 gene expression in triple negative breast cancer
}

\author{
Joe Yeong ${ }^{1,2}$, Jeffrey Chun Tatt Lim ${ }^{1}$, Bernett Lee ${ }^{2}$, Huihua Li ${ }^{3}$, Clara Chong Hui Ong ${ }^{1}$, Aye Aye Thike ${ }^{1,4}$, \\ Wei Hseun Yeap ${ }^{2}$, Yi Yang ${ }^{5,6}$, Ansel Yi Herh Lim7, Timothy Kwang Yong Tay ${ }^{1}$, Jin Liư ${ }^{5}$, Siew-Cheng Wong ${ }^{2}$, \\ Jinmiao Chen ${ }^{2}$, Elaine Hsuen Lim ${ }^{8}$, Jabed lqbal ${ }^{1,4}$, Rebecca Dent ${ }^{*^{*}}$, Evan W. Newell ${ }^{2^{*}}$ and Puay Hoon Tan ${ }^{1,4^{*}}$
}

\begin{abstract}
The role of programmed cell death protein-1 (PD-1)/programmed cell death ligand 1 (PD-L1) in triple negative breast cancer (TNBC) remains to be fully understood. In this study, we investigated the role of PD-1 as a prognostic marker for TNBC in an Asian cohort $(n=269)$. Samples from patients with TNBC were labeled with antibodies against PD-L1 and PD-1, and subjected to NanoString assays to measure the expression of immune-related genes. Associations between disease-free survival (DFS), overall survival (OS) and biomarker expression were investigated. Multivariate analysis showed that tumors with high PD-1 ${ }^{+}$immune infiltrates harbored significantly increased DFS, and this increase was significant even after controlling for clinicopathological parameters (HR 0.95; $P=0.030$ ). In addition, the density of cells expressing both CD8 and PD-1, but not the density of CD8 ${ }^{-}$PD- $1^{+}$immune infiltrates, was associated with improved DFS. Notably, this prognostic significance was independent of clinicopathological parameters and the densities of total $C D 8^{+}$cell $(H R 0.43, P=0.011)$. At the transcriptional level, high expression of PDCD1 within the tumor was significantly associated with improved DFS (HR 0.38; $P=0.027$ ). In line with these findings, high expression of IFNG (HR 0.38; $P=0.001$ ) and IFN signaling genes (HR 0.46; $p=0.027$ ) was also associated with favorable DFS. Inclusion of PD-1 immune infiltrates and PDCD1 gene expression added significant prognostic value for DFS $\left(\Delta \mathrm{LRX}^{2}=6.35\right.$; $P=0.041)$ and $O S\left(\Delta L R x^{2}=9.53 ; P=0.008\right)$, beyond that provided by classical clinicopathological variables. Thus, PD-1 mRNA and protein expression status represent a promising, independent indicator of prognosis in TNBC.
\end{abstract}

Keywords: TNBC, PD-1, PD-L1, Immune checkpoint, IFNG

\section{Introduction}

Triple negative breast cancer (TNBC) accounts for 9$17 \%$ of all breast cancer diagnoses [1-3] and is defined by the absence of estrogen receptor (ER), progesterone receptor (PR) and c-erbB2 (HER2) expression. Although TNBC is histopathologically heterogeneous, these tumors share common clinical challenges. Patients frequently

\footnotetext{
* Correspondence: rebecca.dent@singhealth.com.sg;

evan_newell@immunol.a-star.edu.sg; tan.puay.hoon@singhealth.com.sg ${ }^{8}$ National Cancer Centre Singapore, 11 Hospital Drive, Singapore 169610, Singapore

${ }^{2}$ Singapore Immunology Network (SIgN), Agency of Science, Technology and Research (A*STAR), 8A, Biomedical Grove, Immunos, Singapore 138648, Singapore

'Division of Pathology, Singapore General Hospital, 20 College Road, Academia, Level 7, Singapore 169856, Singapore

Full list of author information is available at the end of the article
}

present with advanced disease, suffer a high incidence of metastasis and recurrence, and have significantly poorer prognosis than patients whose tumors express the aforementioned receptors [4-6]. Oncologic management options are limited due to the lack of therapeutic targets. As a result, almost $50 \%$ of patients with TNBC succumb to the disease within 5 years of diagnosis [5].

The recent success of immunotherapy targeting programmed cell death protein-1 (PD-1)/programmed cell death ligand 1 (PD-L1) in other cancers, such as non-small cell lung cancer and melanoma, has yet to be achieved in TNBC regardless of which monoclonal antibodies (including pembrolizumab, durvalumab, atezolizumab and avelumab) are used [7-15]. However, TNBC harbors relatively high numbers of tumor-infiltrating

(c) The Author(s). 2019 Open Access This article is distributed under the terms of the Creative Commons Attribution 4.0 International License (http://creativecommons.org/licenses/by/4.0/), which permits unrestricted use, distribution, and 
lymphocytes (TILs) [16-18], frequently expresses higher levels of PD-L1 [19-21] and has an elevated tumor mutational burden [22, 23] compared with other breast cancer subtypes. Therefore, in order to identify novel targets for immunotherapy and those individuals most likely to respond to treatment, further elucidation of the TNBC immune microenvironment is necessary.

Immune cells are known to be a determining factor in tumor initiation, progression and metastasis [24, 25], but understanding precisely which cell types act to promote or prevent disease, and under what circumstances, have proven challenging. For example, during the immunoediting process [26, 27], TILs and the immune system serve different roles in the three $\mathbf{E}$ phases. These include the initial phase of cancer cell Elimination, an Equilibrium phase during which the surviving cancer cells undergo immune-mediated dormancy and, ultimately, Escape from immunosurveillance in the final phase. In breast cancer, high TIL levels are associated with reduced survival in patients with $\mathrm{ER}^{+}$breast tumors, but this same feature is associated with a significantly increased survival time in TNBC $[4,28-30]$. The mere presence of TILs is therefore an insufficient predictor of their influence. For this reason, there remains an urgent need to characterize the TIL compartment more thoroughly, particularly in the context of concurrent loss of hormone receptors and HER2 expression. In addition to $\mathrm{T}$ and $\mathrm{B}$ cells, natural killer cells and macrophages may also infiltrate tumors, but the role served by $\mathrm{PD}-1^{+} \mathrm{T}$ cells is of particular clinical interest at present [31-39].

PD-1 expression is known to be associated with T cell exhaustion. In a general setting without immunotherapy, high PD- $1^{+} \mathrm{CD}^{+} \mathrm{T}$ cell levels are associated with a poor prognosis in a range of cancers, including liver cancer, pancreatic cancer, early breast cancer and head and neck cancers [40-45]. However, the notion that all PD- $1^{+}$immune cells are "exhausted" and, therefore, that they should be promoting pro-tumor immunity, may be an oversimplification. For example, a recent study demonstrated that tumor-infiltrating $\mathrm{T}$ cells in breast cancer expressed PD-1, but not other markers associated with exhaustion, and that these cells produced similar levels of pro-inflammatory cytokines to effector $\mathrm{T}$ cells [46]. Whether PD-1 is a marker of exhaustion, activation or both remains controversial, and PD-1 expression may only demonstrate that an immune cell has been recently stimulated, and is therefore antigen-experienced [47-51]. Furthermore, PD-1 expression on TILs, especially relative to tumor cell PD-L1 expression, is not a good predictive marker for PD-1/PD-L1 checkpoint blockade immunotherapy $[40,47,52-55]$, and the function of these cells in many types of cancer, including TNBC, is not fully understood.

Considering the evident importance of the PD-1/ PD-L1 pathway in determining clinical outcomes in multiple cancers, and the dearth of knowledge surrounding the involvement of this pathway in TNBCs, our group used multimodal methodologies, including conventional pathology techniques, multiplex immunofluorescent (mIF) staining and NanoString to retrospectively evaluate PD- $1^{+}$total immune infiltrates, the $\mathrm{CD} 8^{+} \mathrm{PD}-1^{+}$ subset, PD-L1 protein expression, and transcript levels of CD274, PDCD1 and IFNG. We subsequently identified the factors among these that were associated with clinical outcomes.

\section{Materials and methods}

\section{Patients and tumors}

A total of 269 archival formalin-fixed, paraffin-embedded (FFPE) TNBC specimens from patients diagnosed between January 2003 and December 2013 at the Department of Anatomical Pathology, Division of Pathology, Singapore General Hospital, were analyzed. All samples were obtained before patients underwent adjuvant chemoor radiotherapy. Clinicopathological parameters, including patient age, tumor size, histologic growth pattern, grade and subtype, associated ductal carcinoma in situ, lymphovascular invasion and axillary lymph node status, are reviewed in Additional file 1: Table S1. The age of patients ranged from 28 to 89 years (median, 55 years) while length of follow-up ranged from 1 to 213 months (mean, 101 months; median, 97 months); with recurrence and death occurring in $65(24 \%)$ and $45(17 \%)$ of these women, respectively. Tumors were typed, staged and graded according to the World Health Organization, American Society of Clinical Oncology-College of American Pathologists (ASCO-CAP) guidelines [47]. The Centralized Institutional Review Board of SingHealth provided ethical approval for the use of patient materials in this study (CIRB ref.: 2013/664/F and 2015/2199).

\section{Tissue microarray (TMA) construction}

Tumor regions for TMA construction were selected based on pathological assessment, which identified samples where $>50 \%$ of the sample area was tumor tissue. For each sample, two or three representative tumor cores of $1 \mathrm{~mm}$ diameter were transferred from donor FFPE tissue blocks to recipient TMA blocks using an MTA-1 Manual Tissue Arrayer (Beecher Instruments, Inc., Sun Prairie, WI, USA). TMAs were constructed as previously described [6].

\section{Immunohistochemical analysis of TMAs}

TMA sections $(4 \mu \mathrm{m}$ thick) were labeled with antibodies against PD-1, PD-L1, CD8, ER, PR and HER2 (Additional file 1: Table S2). We also labeled tumor sections with antibodies against epidermal growth factor receptor (EGFR), cytokeratin (CK) 14 and CK high molecular weight (clone 34ßBE12) to identify TNBC with a basal-like phenotype, 
according to previously published protocols $[6,48]$. Appropriate positive and negative controls were included. Scoring of antibody-labeled sections was performed for nuclear ER and PR, membranous HER2, EGFR and PD-L1, cytoplasmic CK14, 34ßE12 and PD-1, and membranous and/or cytoplasmic CD8 positivity. To generate the scores, images of labeled slides were captured using a ScanScope XT device (Aperio Technologies; Leica Microsystems GmbH, Wetzlar, Germany) or an IntelliSite Ultra-Fast Scanner (Philips Research, Eindhoven, Netherlands) prior to examination by two pathologists blinded to clinicopathological and survival information. ASCO-CAP guidelines were used to define positivity cut-offs for the tumors as follows: a positive ER/PR result was defined as the presence of at least $1 \%$ of tumor cell nuclei displaying unequivocal staining of any intensity, and for HER2, tumor positivity was defined as $>10 \%$ of tumor cells exhibiting $3+$ membrane staining [49]. Ambiguous HER2 cases were tested and confirmed by fluorescence in situ hybridization based on the ASCO/CAP guidelines [50, 51]. CK14, EGFR and $34 \beta E 12$ positivity was also determined in accordance to the aforementioned $1 \%$ cut-off $[6,48]$.

Tumor PD-L1 expression was confirmed when staining of the tumor cell membranes (of any intensity) was observed at prespecified expression threshold levels of $1 \%$ or higher in a TMA core including at least 100 tumor cells that could be evaluated [52-55].

The number of PD- $1^{+}$immune infiltrates was counted for every $1 \mathrm{~mm}$ diameter TMA core, following previously described methods [19, 45, 56-58]. Samples were then grouped into "high" and "low" according to whether the PD- $1^{+}$immune infiltrate count was above the median or equal to/below the median [59-61].

\section{Multiplex immunofluorescence (mIF)}

Multiplex immunofluorescence (mIF) was performed using an Opal Multiplex fIHC kit (PerkinElmer, Inc., Waltham, MA, USA) as previously described by our group and other studies [45, 61-71], on FFPE tissue sections processed according to the standard immunohistochemistry protocol described above. Slides were labeled with primary antibodies against PD- 1 and CD8, followed by appropriate secondary antibodies (as presented in Additional file 1: Table S2), before application of the fluorophore-conjugated tyramide signal amplification buffer (PerkinElmer, Inc., Waltham, MA, USA). DAPI was used as a nuclear counterstain. Images were acquired using a Vectra 3 pathology imaging system microscope (PerkinElmer, Inc.) and analyzed using inForm version 2.3 software (PerkinElmer, Inc.) [63, 72, 73].

CD8 was stained using Opal 540 (Catalog No. FP1494001KT) while PD-1 was stained by using Opal 620 (Catalog NO. FP1495001KT). The counterstain
DAPI was from Catalog No. FP1490. They were purchased from PerkinElmer, Inc., Waltham, MA, USA.

\section{RNA extraction, NanoString measurement of PDCD1 and CD274 expression, and analysis}

RNA was extracted from 8 unlabeled FFPE sections (10 $\mu \mathrm{m}$ thick) using an RNeasy FFPE kit (Qiagen GmbH, Hilden, Germany) on a QIAcube automated sample preparation system (Qiagen $\mathrm{GmbH}$ ), and was quantified using an Agilent 2100 Bioanalyzer system (Agilent Technologies, Santa Clara, CA, USA). A total of 100 ng of functional RNA (> 300 nucleotides) was assayed on the nCounter MAX Analysis System (NanoString Technologies, Inc., Seattle, WA, USA). The NanoString counts were normalized using positive control probes and the housekeeping genes, as previously reported [61, 71]. The count data were then logarithmically transformed prior to further analysis. $P<0.05$ was considered to indicate a statistically significant difference.

\section{Cell lines and flow cytometry}

All human breast adenocarcinoma cell lines were a gift from Dr. Sandra Hubert (SIgN). BT20, HCC-38, HCC1806, MDA-MB-231, MDA-MB-453 and MDA-MB-468 were maintained in RPMI cultured with $10 \%(v / v)$ heat-inactivated fetal calf serum (HI-FCS, Gibco; Thermo Fisher Scientific, Inc., Waltham, MA, USA), $1 \%(\mathrm{v} / \mathrm{v})$ penicillinstreptomycin (PS) at $37^{\circ} \mathrm{C}$ and $5 \% \mathrm{CO}_{2}$ in a cell culture incubator.

The antibodies to measure protein expression during flow cytometry using the above cell lines were $\alpha$-PDL1 (Clone 29E.2A3, IgG2b, Cat No: 32970, BioLegend, San Diego, CA, USA), $\alpha$-PDL2 (Clone 24F.10CL2, IgG2a, Cat No: 329608, BioLegend) and $\alpha$-HLA-ABC (Clone W6/32, IgG2a, Cat No: 311413, BioLegend). Cell lines were trypsinised using PBS-EDTA. For flow cytometry, 0.5 million cells from each cell line were resuspended in homemade FACs buffer (1x PBS + 0.2 M EDTA + 20\% (v/v) HI-FCS $+20 \%(\mathrm{v} / \mathrm{v})$ human serum), incubated with various antibodies for $20 \mathrm{~min}$ at $4{ }^{\circ} \mathrm{C}$ and analyzed using FACSAria II with 4 lasers (BD Biosciences, San Jose, CA, USA).

\section{Gene heat map, validation, follow-up and statistical analysis}

Follow-up data were obtained from medical records. Disease-free survival (DFS) and overall survival (OS) were defined as the time from diagnosis to recurrence or death/date of last follow-up, respectively. Statistical analysis was performed using SPSS 23.0 for Windows (IBM Corp., Armonk, NY, USA). The associations between clinicopathological parameters and the frequency of PD $-1^{+}$immune infiltrates and PD- $1^{+}$tumor cells were 
tested using $x^{2}$ and Fisher's exact tests. Survival outcomes were estimated using Kaplan-Meier analysis and groups were compared using log-rank statistics. Multivariate Cox regression was performed to evaluate the effect of PD-1 and PD-L1 status and the NanoString $P D C D 1$ and $C D 274$ counts on survival, after adjusting for clinicopathological parameters including patient age, tumor size, tumor grade and lymph node status. NanoString percentile thresholds for $P D C D 1$ and $C D 274$ were tested using log-rank statistics for OS, and the best percentile thresholds were used to define the PDCD1 and $C D 274$ double-positive samples. Gene expression percentile thresholds for PDCD1 and CD274 were determined in the same fashion, using public data from METABRIC, and then used to define the PDCD1 and CD274 double-positive samples. Gene expression and survival data for METABRIC and The Cancer Genome Atlas (TCGA) were obtained from cBioPortal for validation purposes, after filtering for TNBC samples. Models were compared using the increment in the log-likelihood of the models $\left(\triangle \mathrm{LRX} \chi^{2}\right)$ using a likelihood ratio test. $P<0.05$ was considered to indicate a statistically significance difference.

\section{Results}

\section{Patients with tumors harboring a high density of PD-1+} immune cells have improved clinical outcomes

Tissue sections from TNBC were incubated with antibodies targeting PD-1 to allow identification of total PD- $1^{+}$immune infiltrates (Fig. 1a-d). The number of
PD- $1^{+}$immune infiltrates was counted in every $1 \mathrm{~mm}$ diameter TMA core, following previously published methods [19, 45, 56-58]. Samples were then grouped according to whether their PD- $1^{+}$immune infiltrates counts were high (above the median), or low (equal to/below the median). Meanwhile, PD-L1 expression was quantified as a tumor proportion score, as previously described [52-55].

In the case of total $\mathrm{PD}^{+}$immune infiltrates, $46.6 \%$ of the TNBC samples were determined to have high levels of $\mathrm{PD}^{+}$immune infiltrates, and $26.5 \%$ of samples were determined to have high PD-L1 tumor cell protein expression (Additional file 1: Table S3). Univariate analysis of the clinicopathological features of high and low PD-1 immune infiltrates and PD-L1 tumor cell expression revealed that tumors with high levels of PD-1 immune infiltrates were significantly more likely to lack lymphovascular invasion $(P=0.034$; Additional file 1: Table $S 1)$, which is a key feature reflecting tumor aggressiveness $[74,75]$.

We then investigated whether PD- $1^{+}$immune infiltrates in tumors had any effect on outcomes in patients with TNBC. As presented in Fig. 1e-h, Kaplan-Meier survival analysis revealed that TNBC patients in the "high PD- $1^{+}$ immune infiltrates" group had significantly improved OS and DFS compared with those in the "low PD- $1^{+}$immune infiltrates" group (OS, $P=0.01$; DFS, $P=0.002$ ). Interestingly, Kaplan-Meier survival analysis also revealed that the "high PD-L1 tumor cell expression" group had improved DFS compared with the "low PD-L1 tumor cell expression group" $(P=0.006)$, while OS was not significantly different between the groups $(P=0.070)$.

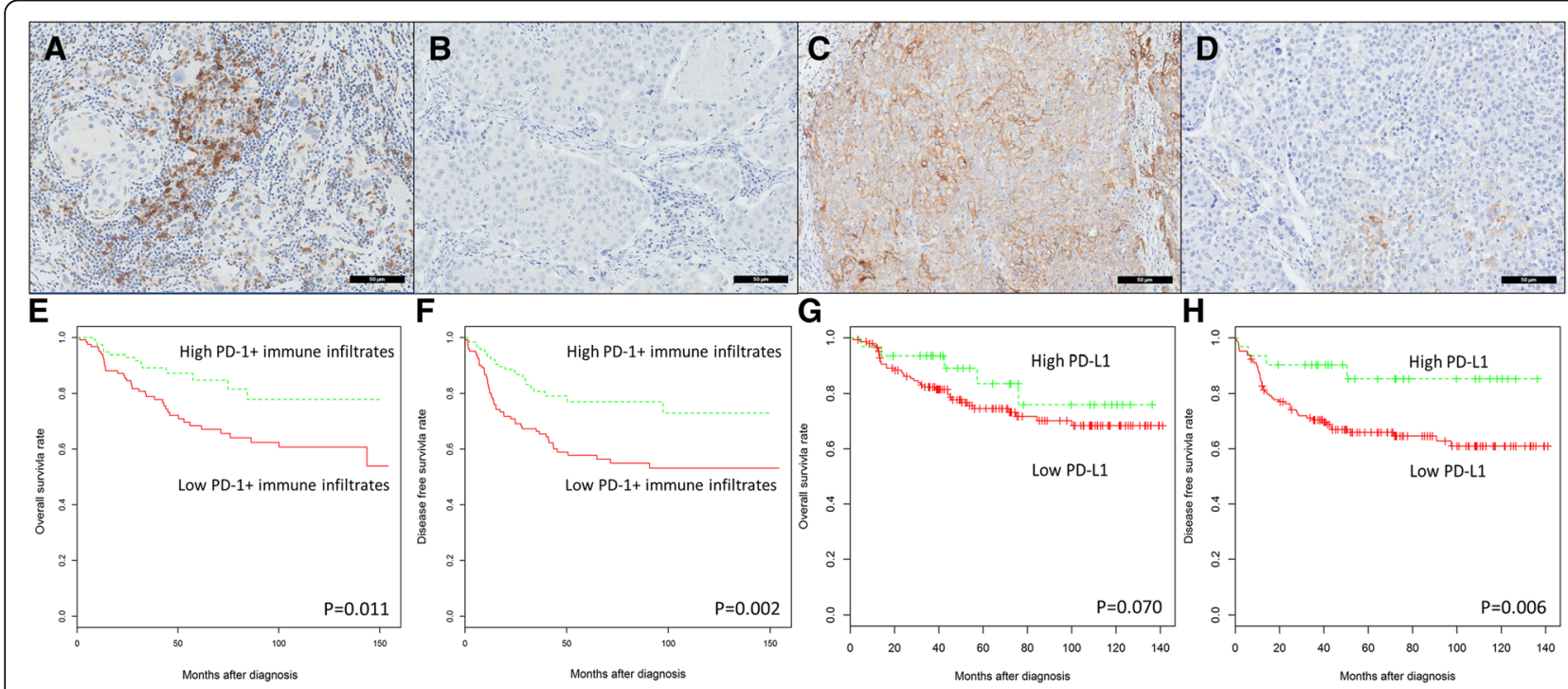

Fig. 1 PD- $1^{+}$immune infiltrates and PD-L1 tumor cell expression in TNBC. Representative immunohistochemical staining showing a high and $\mathbf{b}$ low PD-1 ${ }^{+}$immune infiltrates; and $\mathbf{c}$ high and $\mathbf{d}$ low PD-L1 tumor cell expression in TNBC sections (magnification, 100x). High PD- $1^{+}$immune infiltrates and PD-L1 tumor cell expression are associated with improved survival in TNBC. Kaplan-Meier analysis of e OS and $\mathbf{f}$ DFS outcomes in women with high versus low densities of PD-1 ${ }^{+}$immune infiltrates. Kaplan-Meier analysis of $\mathbf{g}$ OS and $\mathbf{h}$ DFS outcomes in women with high versus low PD-L1 tumor cell expression 
Multivariate analysis further supported the association between a high density of PD- $1^{+}$immune infiltrates in TNBC and a significantly improved DFS (HR $=0.48$; $95 \%$ CI $0.29-0.81 ; P=0.005)$, and this effect was evident at every 1 cell increment of PD-1 immune infiltrate density (Table 1 ). In other words, every incremental 1 cell per 1 $\mathrm{mm}$ core was associated with improved DFS $(\mathrm{HR}=0.95$; 95\% CI 0.93-1.00; $P=0.030$ ). Multivariate analysis similarly demonstrated that high PD-L1 tumor cell expression was associated with improved OS $(\mathrm{HR}=0.40 ; 95 \%$ CI $0.18-0.86 ; P=0.020)$ and DFS (HR $=0.39 ; 95 \% \mathrm{CI}$ 0.20-0.76; $P=0.006)$.

Furthermore, Opal mIF staining [45, 62-71] for PD-1 and CD8 was performed on TNBC sections, followed by image acquisition with a Vectra 3 pathology imaging system and image analysis with inForm software [63, 72, 73]. Notably, the immune subsets that expressed both CD8 and PD-1 (Fig. 2a-d) were associated with improved survival (Fig. 2e-f), but $\mathrm{CD} 8^{-} \mathrm{PD} 1^{+}$immune infiltrates were not (Fig. 2a-d and g-h). Multivariate analysis revealed that the $\mathrm{CD}^{+} \mathrm{PD}^{+}$double positive immune subset was an independent prognostic marker for improved DFS $(\mathrm{HR}=0.45 ; 95 \%$ CI $0.28-0.80 ; P=0.006)$, even when adjusted for both clinicopathological parameters and total $\mathrm{CD}^{+} \mathrm{T}$ cell counts $(\mathrm{HR}=0.43 ; 95 \% \mathrm{CI}$ $0.23-0.83 ; P=0.011$ ) (Table 2 ) the latter previously reported by our group, to highlight the prognostic influence of intratumoral $\mathrm{CD}^{+} \mathrm{T}$ cell density in TNBC [60].

\section{Higher PD-1 and PD-L1 gene expression is associated with an improved clinical outcome in TNBC}

There was evidence of a significant positive correlation between the densities of PD- $1^{+}$immune infiltrates and

Table 1 Multivariate analysis of PD- $1^{+}$immune infiltrates and PD-L1 tumor cells with survival outcomes in patients with TNBC. Analysis was adjusted for tumor size, grade, age and lymph node status

\begin{tabular}{|c|c|c|c|}
\hline Biomarkers & $\mathrm{HR}$ & $95 \% \mathrm{Cl}$ & $P$-value \\
\hline \multicolumn{4}{|l|}{ OS } \\
\hline $\begin{array}{l}\mathrm{PD}-1^{+} \text {immune infiltrates } \\
\text { High vs. low }\end{array}$ & 0.61 & $0.33-1.13$ & 0.110 \\
\hline $\begin{array}{l}\text { PD- } 1^{+} \text {immune infiltrates } \\
\text { (every } 1 \text { cell increment) }\end{array}$ & 0.96 & $0.91-1.01$ & 0.080 \\
\hline $\begin{array}{l}\text { PD-L1 expression } \\
\text { High vs. low }\end{array}$ & 0.40 & $0.18-0.86$ & $0.020^{*}$ \\
\hline \multicolumn{4}{|l|}{ DFS } \\
\hline $\begin{array}{l}\text { PD- } 1^{+} \text {immune infiltrates } \\
\text { High vs. low }\end{array}$ & 0.48 & $0.29-0.81$ & $0.005^{*}$ \\
\hline $\begin{array}{l}\text { PD- } 1^{+} \text {immune infiltrates } \\
\text { (every } 1 \text { cell increment) }\end{array}$ & 0.95 & $0.93-1.00$ & $0.030^{*}$ \\
\hline $\begin{array}{l}\text { PD-L1 expression } \\
\text { High vs. low }\end{array}$ & 0.39 & $0.20-0.76$ & $0.006^{*}$ \\
\hline
\end{tabular}

PD-L1 tumor cell expression $(P<0.0001 ; R=0.303)$ (Additional file 1: Table S4). Meanwhile, correlations between protein and mRNA levels of PD-L1 and PD-1 were clear (PD-L1 vs. CD274, $P<0.0001, R=0.411$; PD-1 vs. $P D C D 1, P<0.0001, R=0.276$; Additional file 1 : Tables S4 and S5, respectively).

We proceeded to examine the link between the expression levels of PDCD1 (encoding PD-1), CD274 (encoding PD-L1), and TNBC prognosis. We utilized a NanoString assay $[76,77]$ to measure PD- $1^{+}$immune infiltrates and PD-L1 tumor cell expression at the transcriptional level in the TNBC samples, and then compared transcript abundance with survival time. As presented in Table 3, every incremental unit of either $P D C D 1$ and $C D 274$ was associated with improved OS (PDCD1, HR 0.02, 95\% CI 0.00-0.36, P=0.007; CD274, HR 0.12, 95\% CI 0.02-0.81, $P=0.030)$ and DFS (PDCD1, HR 0.08, 95\% CI 0.01-0.83, $P=0.034$; CD274, HR 0.19, 95\% CI 0.04-0.97, $P=0.045$ ) even following adjustment for tumor size, grade, age and lymph node status.

These results were confirmed using PDCD1 and CD274 gene expression data from a publicly-available database (EGAS00001001753 from the European Genome-Phenome Archive), which revealed a significant association between increased PDCD1 and CD274 expression and DFS (PDCD1 HR 0.38, 95\% CI 0.15-0.94, $P=0.027$; $C D 274$ HR $0.63,95 \%$ CI $0.42-0.96, P=0.026)$ but not OS (PDCD1 HR 0.55, 95\% CI 0.26-1.12, $P=0.086$; CD274 HR 0.77, 95\% CI 0.55-1.08, $P=0.121$ ) in 320 cases of TNBC (Additional file 1: Table S6).

Given the strong association between PDCD1 and $C D 274$ expression levels and patient survival, a group of TNBC patient samples which harbored high PDCD1 and high $C D 274$ was defined. The expression levels of both genes were higher than the optimal percentile threshold in these patients, as determined using OS. With this definition, as expected, the prognostic value of these two markers in combination was still present, with the high PDCD1 and high CD274 group being associated with improved OS $(P=0.003)$ and DFS $(P=0.005)$, compared with the rest of the patients (Fig. 3a-b).

We then investigated the overall gene expression profiles of tumors from high PDCD1 and high CD274 patients, compared with the rest of the patients, to look for additional molecular correlates that could explain differences between the tumors of these patients. A customized panel of a NanoString assay was utilized to measure the expression of a panel of 499 immune and cancer-associated genes in the TNBC cohort [59, 78-84]. One way ANOVA followed by post hoc t-tests revealed that 77 genes were significantly differentially expressed, with a fold-change of $>2$ fold, between TNBC cases that harbored both high $P D C D 1$ and high $C D 274$ expression and the rest of the cases (Additional file 1: Figure S1). 

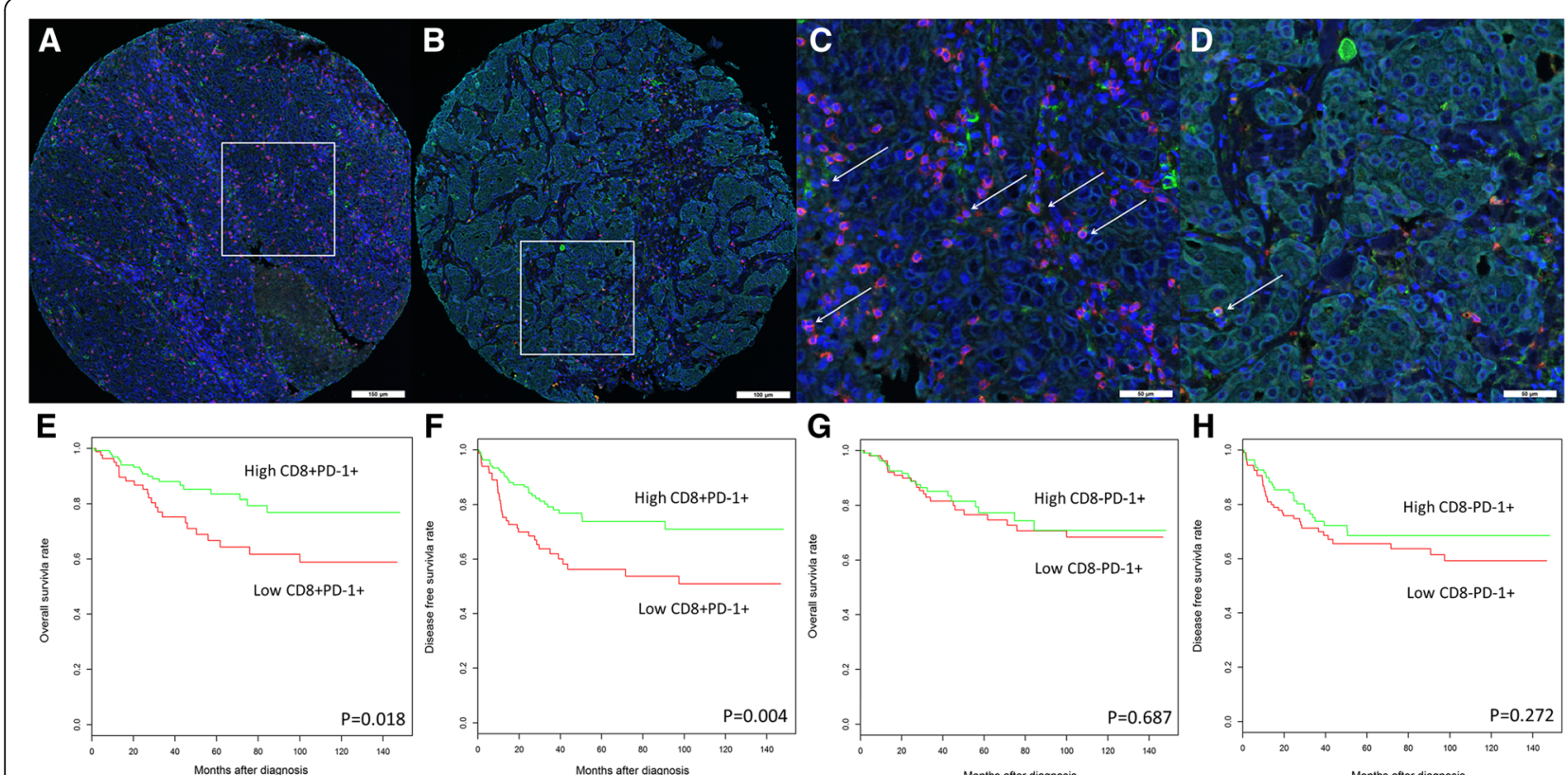

Fig. 2 PD $-1^{+}$immune infiltrates have at least two subsets in relation to CD 8 cells in TNBCs; the CD8 ${ }^{+} \mathrm{PD}-1^{+}$double positive subset and the CD8 ${ }^{-}$PD $-1^{+}$subset. mIF labeled sections from two representative TNBC tissue samples show the PD- ${ }^{+}, \mathrm{CD} 8^{+}$, the $\mathrm{CD} 8^{+} \mathrm{PD}-1^{+}$double positive subset and the CD8 ${ }^{-}$PD-1 ${ }^{+}$subset within the tumor microenvironment. mIF labeling for PD-1 (green), CD8 (red), Pan-cytokeratin (cyan) and DAPI (blue). a TNBC harbored high CD8 ${ }^{+}$PD- $1^{+}$double positive subset. $\mathbf{b}$ TNBC harbored low CD8 ${ }^{+}$PD- $1^{+}$double positive subset. $\mathbf{c}$ and $\mathbf{d}$ Higher magnification of the same region from images ( $\mathbf{a}$ and $\mathbf{b}$, respectively) shows CD8 ${ }^{+} \mathrm{PD}-1^{+}$double positive subset through double labeling of CD8 (red) and PD-1 (green), indicated by white arrows. High levels of CD8 ${ }^{+}$PD- $1^{+}$infiltrates, but not high levels of CD8 ${ }^{-}$PD- $1^{+}$immune infiltrates, are associated with improved survival in TNBC. Kaplan-Meier analysis of e OS and $\mathbf{f}$ DFS outcomes in women with high versus low densities of CD $8^{+}$PD- $1^{+}$double positive immune infiltrates. Kaplan-Meier analysis of $\mathbf{g}$ OS and $\mathbf{h}$ DFS outcomes in women with high versus low CD8 ${ }^{-}$PD- $1^{+}$immune infiltrates

Ingenuity Pathway Analysis (IPA) was used to decipher the biological functions of the 77 differentially-expressed genes (DEGs). Core analysis in IPA identified significant functional enrichment in the expression of genes associated with canonical pathways: "communication between innate and adaptive immunity" $(P=0.003)$ and "Interferon signaling" $(P=0.008)$. Furthermore, IPA upstream regulator analysis also revealed that interferon gamma (IFNG) was enriched $(P=0.001)$.

The prognostic value of the CD274 and PDCD1 combination and the DEGs was validated by the aforementioned publicly-available database (EGAS00001001753 from the European Genome-Phenome Archive [85]; Fig. 3c-d). Interestingly, as presented in the volcano

Table 2 Multivariate analysis of CD8 ${ }^{+} \mathrm{PD}-1^{+}$double positive immune subsets with survival outcomes in patients with TNBC. Analysis was adjusted for tumor size, grade, age and lymph node status

\begin{tabular}{|c|c|c|c|}
\hline Biomarkers & $\mathrm{HR}$ & $95 \% \mathrm{Cl}$ & $P$-value \\
\hline \multicolumn{4}{|l|}{ OS } \\
\hline $\begin{array}{l}\text { CD } 8^{+} \text {PD- } 1^{+} \text {immune infiltrates } \\
\text { High vs. low }\end{array}$ & 0.56 & $0.29-1.06$ & 0.073 \\
\hline $\begin{array}{l}\mathrm{CD} 8^{+} \mathrm{PD}-1^{+} \text {immune infiltrates } \\
\text { High vs. low (adjusted for tumor size, grade, age and } \\
\text { lymph node status and CD } 8^{+} \text {total cell count) }\end{array}$ & 0.77 & $0.35-1.67$ & 0.510 \\
\hline \multicolumn{4}{|l|}{ DFS } \\
\hline $\begin{array}{l}\text { CD } 8^{+} \text {PD- } 1^{+} \text {immune infiltrates } \\
\text { High vs. low }\end{array}$ & 0.47 & $0.28-0.80$ & $0.006^{*}$ \\
\hline $\begin{array}{l}\text { CD } 8^{+} \text {PD }-1^{+} \text {immune infiltrates } \\
\text { High vs. low (adjusted for tumor size, grade, age and } \\
\text { lymph node status and } C D 8^{+} \text {total cell count) }\end{array}$ & 0.43 & $0.23-0.83$ & $0.011^{*}$ \\
\hline
\end{tabular}

PD-1 programmed cell death protein-1, PD-L1 programmed cell death ligand 1 
Table 3 Multivariate analysis of PDCD1, CD274, IFNG and IFN signaling genes RNA expression survival outcomes in patients with TNBC. Analysis was adjusted for tumor size, grade, age and lymph node status

\begin{tabular}{llll}
\hline Biomarkers & HR & $95 \% \mathrm{Cl}$ & $P$-value \\
\hline OS & & & \\
PDCD1 expression (every 1 unit increment) & 0.02 & $0.00-0.36$ & $0.007^{*}$ \\
CD274 expression (every 1 unit increment) & 0.12 & $0.02-0.81$ & $0.030^{*}$ \\
$\begin{array}{l}\text { IFNG expression } \\
\text { High vs. low }\end{array}$ & 0.38 & $0.21-0.72$ & $0.003^{*}$ \\
Interferon signaling gene expression & 0.59 & $0.29-1.17$ & 0.132 \\
High vs. low & & & \\
DFS & & & \\
PDCD1 expression (every 1 unit increment) & 0.08 & $0.01-0.83$ & $0.034^{*}$ \\
CD274 expression (every 1 unit increment) & 0.19 & $0.04-0.97$ & $0.045^{*}$ \\
IFNG expression & 0.38 & $0.22-0.68$ & $0.001^{*}$ \\
High vs. low & & & \\
Interferon signaling gene expression & 0.46 & $0.23-0.92$ & $0.027^{*}$ \\
High vs. low & & & \\
\hline
\end{tabular}

*Statistically significant

plots (Fig. 3e-g), CD3 and CD8 genes, along with IFNG and major histocompatibility complex class I (MHC-I) genes ( $H L A-A, H L A-B$ and $H L A-C)$, were among the highly expressed DEGs in the high CD274 and high $P D C D 1$ expression group. This finding was consistent across three cohorts, which included public data such as METABRIC [85] and TCGA [22] (Additional file 1: Figure S2) which was obtained from cBioPortal [86, 87], as well as our own cohort.

The increase of PD-L1 and the reduction of MHC-I have long been considered one of the key events and mechanisms underlying immune escape [88-91]. However, our group found that $C D 274$ gene expression was significantly associated with $H L A-A, H L A-B$ and $H L A-C$ expression, as shown in Additional file 1: Table S7. This result was further supported through the use of human TNBC cell lines, with flow cytometry staining performed to determine the expression of PD-L1 and MHC-I $(R=0.89$; Additional file 1: Figure S3).

Based on the IPA canonical pathway analysis and the upstream regulator analysis showing that IFNG is enriched based on the DEGs and because IFNG represents a critical cytokine in immunoediting [92-94] and is functionally linked to PD-L1 and PD-1 [95], we further investigated the prognostic role of IFNG in this cohort. As presented in Fig. 3h-i, high IFNG expression is associated with favorable DFS $(P=0.006)$ and OS $(P=0.002)$. As shown in Table 3 , multivariate analysis further confirmed this result following adjustment of clinicopathological parameters (DFS HR 0.38, 95\% CI $0.22-0.68 ; P=0.0009$; OS HR 0.38, 95\% CI 0.21-0.72; $P=0.0027)$. Furthermore, 5 genes which are demonstrated in the IPA canonical pathway analysis as "Interferon signaling", and their expression levels were examined in this TNBC cohort as shown in Additional file 1: Figure S4., Unsupervised hierarchical analysis revealed the existence of two distinct clusters of TNBC (Additional file 1: Figure S4): cluster 1 (green) contained TNBC with higher IFN signaling gene expression, with these patients exhibiting significantly improved DFS $(P=0.036)$ as shown in Fig. 3j-k, but not OS, compared with the low IFN-signaling-gene-expressing cluster 2 (red). This finding is further confirmed with multivariate analysis (HR 0.46 95\% CI $0.23-0.92 ; P=0.027$ ) as shown in Table 3.

\section{PD- $1^{+}$immune infiltrates, PD-L1 tumor cell expression and the expression of CD274 and PDCD1 add significant prognostic power to classical clinicopathological parameters}

To further demonstrate the prognostic power of the PD-1/PD-L1-associated measures reported in the present study, we examined the impact of incorporating their effects into survival outcome analysis with a panel of typical clinicopathological features (patient age, tumor grade, tumor size and lymph node status). As presented in Table 4, the addition of PD-L1 ${ }^{+}$tumor cells to clinicopathological features significantly increased the prognostic value for DFS $\left(\Delta \mathrm{LRX}{ }^{2}=5.22 ; P=0.022\right)$, and OS $\left(\Delta \mathrm{LRX}^{2}=3.95 ; P=0.047\right)$. On the other hand, the addition of PD- $1^{+}$immune infiltrate density to clinicopathological features significantly increased the prognostic value for DFS $\left(\Delta \mathrm{LRX}^{2}=4.18 ; P=0.028\right)$, but not OS, compared with clinicopathological features alone. Meanwhile, the inclusion of $P D C D 1$ gene expression increased the prognostic value for both DFS $\left(\Delta \mathrm{LRX}^{2}=4.12\right.$; $P=0.043)$ and OS $\left(\Delta \mathrm{LRX}^{2}=6.55 ; P=0.011\right)$. Of the multiple proteins, genes and combinations, $\mathrm{PD}-1^{+}$immune infiltrates combined with $P D C D 1$ gene expression conferred the best added prognostic value for both DFS $\left(\Delta \mathrm{LRX}^{2}=6.35 ; P=0.042\right)$ and $\mathrm{OS}\left(\Delta \mathrm{LRX}^{2}=9.53 ; P=\right.$ 0.009). Notably, for DFS alone, the $C D 8^{+} \mathrm{PD}-1^{+}$double positive immune subset offered the best prognostic value $\left(\Delta \mathrm{LRX}^{2}=7.53 ; P=0.006\right)$. In addition, IFNG alone showed good prognostic value for both DFS $\left(\Delta \mathrm{LRX}^{2}=7.50\right.$; $P=0.006)$ and $\mathrm{OS}\left(\Delta \mathrm{LRX}{ }^{2}=5.29 ; P=0.022\right)$.

\section{Discussion}

In the present study, we demonstrated that patients bearing TNBC with high PD-1 $1^{+}$immune infiltrates and high PD-L1 tumor expression were likely to experience significantly improved clinical outcomes, and this was validated both at the transcriptional level as well as through a separate cohort, using publicly accessible data. Furthermore, our results demonstrated that it is the $\mathrm{CD} 8^{+} \mathrm{PD}-1^{+}$double-positive immune subset specifically that offers prognostic value, while the $\mathrm{CD} 8^{-} \mathrm{PD}-1^{+}$ 


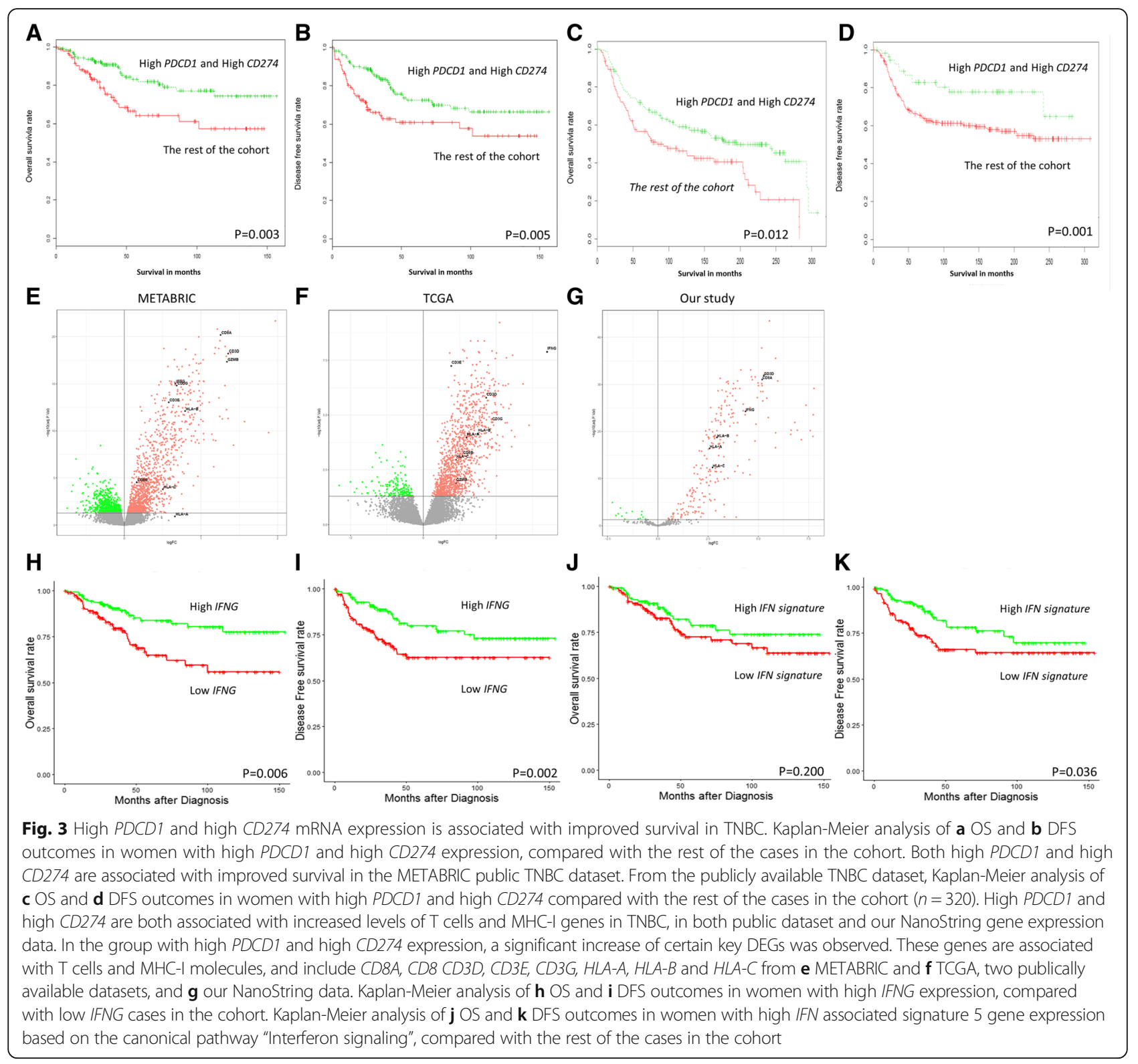

immune subset does not. Also, scoring of whole sections showed statistically significant correlation with that on TMAs for $\mathrm{PD}-1^{+}$immune infiltrates. (Additional file 1: Figure S5A and B).

To the best of our knowledge, this report is the first to highlight the prognostic value of $\mathrm{PD}-1^{+}$, as well as CD $8^{+} \mathrm{PD}-1^{+}$immune infiltrates, through multivariate analysis and $\mathrm{mIF}$, and to highlight the significant correlation with PD-L1 expression in tumor cells in TNBC. Similar associations between high PD-L1 expression in tumor cells and improved prognosis have been reported in several recent studies concerning TNBC [55, 96-99] as well as hormone receptor-positive breast cancers [100-104]. However, some reports have suggested that PD-L1 may be a prognostic marker of breast cancer in general, but one that is associated with worse prognosis [21, 105-108]. This would suggest that for non-TNBC, PD-L1 expression may not be a particularly robust prognostic marker. One possibility is that the prognostic impact of PD-L1 is dependent on the hormone receptor status of the tumor, suggesting either direct or indirect roles of hormone receptors in the regulation of tumor immunity; a topic that warrants further investigation.

In addition to the hormone receptor status of the tumor, infiltrating immune cells and MHC-I may be key to the prognostic significance of the PD-L1/PD-1 pathway. Therefore, our investigations focused primarily on PD $-1^{+}$immune infiltrates. By comparing the prognostic models with a likelihood ratio test, using the increment in the log-likelihood of the models $\left(\Delta \mathrm{LRX}^{2}\right)$, we 
Table 4 Table showing the change in the log-likelihood of the models with added prognostic terms. Statistical significance of the change was determined by a likelihood ratio test

\begin{tabular}{|c|c|c|c|c|}
\hline \multirow[t]{2}{*}{ Variables } & \multicolumn{2}{|l|}{ DFS } & \multicolumn{2}{|l|}{ OS } \\
\hline & $\overline{\Delta L R X^{2}}$ & $P$-value & $\overline{\Delta L R X^{2}}$ & $P$-value \\
\hline $\mathrm{CP}+\mathrm{PD}-1$ vs. $\mathrm{CP}$ & 4.83 & $0.0280^{*}$ & 2.95 & 0.0856 \\
\hline$C P+P D-L 1$ vs. CP & 5.22 & $0.0224^{*}$ & 3.95 & $0.0469^{*}$ \\
\hline $\mathrm{CP}+\mathrm{CD} 274$ vs. $\mathrm{CP}$ & 3.66 & 0.0559 & 4.32 & $0.0378^{*}$ \\
\hline$C P+P D C D 1$ vs. $C P$ & 4.12 & $0.0425^{*}$ & 6.55 & $0.0105^{*}$ \\
\hline $\mathrm{CP}+\mathrm{CD} 274+\mathrm{PDCD} 1$ vs. $\mathrm{CP}$ & 4.49 & 0.1057 & 6.12 & $0.0469^{*}$ \\
\hline $\mathrm{CP}+\mathrm{PD}-\mathrm{L} 1+\mathrm{CD} 274$ vs. CP & 4.11 & 0.1278 & 7.02 & $0.0299^{*}$ \\
\hline $\mathrm{CP}+\mathrm{PD}-1^{+}+\mathrm{PDCD} 1$ vs. $\mathrm{CP}$ & 6.35 & $0.0417^{*}$ & 9.53 & $0.0085^{*}$ \\
\hline $\mathrm{CP}+\mathrm{CD} 8^{+} \mathrm{PD}-1^{+}$vs. $\mathrm{CP}$ & 7.53 & $0.0061^{*}$ & 3.16 & 0.0753 \\
\hline$C P+I F N G$ vs. CP & 7.50 & $0.0062^{*}$ & 5.29 & $0.0214^{*}$ \\
\hline
\end{tabular}

$C P$ Clinicopathological parameters (patient age, tumor grade, tumor size and lymph node status), $P D-1^{+}$PD- $1^{+}$immune infiltrates (every 1 cell increment), $P D-L 1$ PD-L1 tumor cell expression, $L R$ Likelihood Ratio, $C D 8^{+} P D-1^{+} C D 8^{+} P D-1^{+}$ T cells

*Statistically significant

demonstrated that a combination of PD- $1^{+}$immune infiltrates and $P D C D 1$ gene expression offered the highest additional prognostic value for both OS and DFS, compared with traditionally used clinicopathological parameters (Table 4), including patient age, tumor size, tumor grade and lymph node status. These results, together with the finding that $C D 274$ or PDCD1 may be used as independent prognostic markers, suggest a potential clinical application where mRNA levels may be used as a prognostic platform alone or combined with immunohistochemistry-based protein evaluation.

IPA of the 77-gene signature observed in the high $P D C D 1$ and $C D 274$ group in TNBC identified 12 genes associated with the canonical pathway "Communication between innate and adaptive immunity" (IFNG, CCL5, CCR7, CD4OLG, CD8A, CXCL10, HLA-DRB3, IGHA1, IGHD, IGHG1, IGHG3 and IGHM) and 4 genes associated with canonical pathway "Interferon signaling" (MX1, STAT1, TAP1, IRF1). The association with these genes is worthy of further study, as this may improve our understanding of TIL subsets; including macrophages, $\mathrm{CD}^{+} \mathrm{T}$ cells, $\mathrm{B}$ cells or plasma cells. As mentioned above, the inverse relationship between PD-L1 and MHC-I has been thought to be the mechanism underlying tumor escape from immune surveillance [88-91]. In the present study, we also demonstrated a strong positive association between PD-L1 and MHC-I at both the protein (Additional file 1: Figure S3) and mRNA (Additional file 1: Table S7) levels, which may explain why high PD-L1 expression in TNBC does not indicate a suppressive immune microenvironment or a poor prognosis. Furthermore, multiple interferon genes in the 77-gene list, including IFNG, MX1, IRF1, IRF8, STAT1, CXCL9, CXCL10 and CXCL11, and particularly
IFNG, have been demonstrated to be involved in immunoediting, and functionally related to PD-L1 and PD-1 [92-95]. IPA upstream regulator analysis further confirmed that IFNG was a significant common upregulator of these DEGs. Thus, their prognostic values were further investigated, and IFNG and certain related genes in the canonical pathway "Interferon signaling" were revealed to be of prognostic value in TNBC (Fig. 3h-k, Table 3), and were associated with PD-L1/PD-1 expression (Additional file 1: Tables S4, S5 and S7). This mechanism requires further detailed studies for confirmation. The antigen presentation may not have been impaired in the tumor in this case; rather, it may be accentuated.

Are PD- $1^{+}$immune cells, particularly $\mathrm{CD} 8^{+} \mathrm{T}$ cells, exhausted and therefore not functional? This question is commonly asked within the field of oncoimmunology. An increasing number of studies has suggested that PD-1 is not necessarily a marker of exhaustion, but also a marker of $\mathrm{T}$ cell activation and recent TCR signaling [109-114]. As it has also been reported as a marker of tumor reactivity [111], elevated numbers of $\mathrm{PD}-1^{+} \mathrm{CD} 8^{+}$ $\mathrm{T}$ cells may also be reflective of higher numbers of tumor-specific $\mathrm{T}$ cells, which may be associated with improved patient outcomes. Along these lines, three previous studies have suggested that the immunosuppressive ATP ecto-nucleotidase CD39 is also an important marker of chronically stimulated and exhausted $\mathrm{CD} 8^{+} \mathrm{T}$ cells [114-116], is specific to both viral infections and the tumor microenvironment, and appears to be associated with tumor reactivity in the latter [116]. This suggests that PD-1 by itself does not define T cell exhaustion. Thus, it seems that expression of exhaustion-associated markers is associated with tumor reactivity and, in some cases, these cells may still be important for tumor control [46]. It should be noted that Odorizzi et al. [108] demonstrated that $\mathrm{T}$ cells can be differentiated to reach terminal exhaustion in the genetic absence of PD-1. In terms of defining $\mathrm{T}$ cell exhaustion, multiple reports have suggested the combination of PD-1 and transcription factor Eomesodermin (EOMES) might be more accurate [36, 117$120]$, and this warrants further study in a breast cancer setting. A recent breast cancer study also revealed that there is no significant reduction in cytokine production in PD- $1^{+} \mathrm{T}$ cells compared with PD- $1^{-} \mathrm{T}$ cells. Furthermore, PD- $1^{+} \mathrm{T}$ cells do not co-express LAG-3, TIM-3 or CTLA-4, which may suggest that PD-1 $1^{+} \mathrm{T}$ cells in breast cancer may not suffer from exhaustion, or at least support the argument that PD-1 expression alone does not indicate $\mathrm{T}$ cell exhaustion [46]. Overall, our results suggest that PD-1 expression on $\mathrm{CD}^{+} \mathrm{T}$ cells in TNBC does not preclude the ability of these cells to contribute to the control of tumor growth, since patients with more $\mathrm{CD} 8^{+} \mathrm{PD}-1^{+}$double positive immune subsets experienced significantly improved DFS (independent of overall CD8 
densities). This suggests that patients with more $\mathrm{CD} 8^{+} \mathrm{PD}-1^{+} \mathrm{T}$ cells infiltrating tumor tissues experience a lower risk of recurrence.

Our data demonstrated that it is the CD8 ${ }^{+} \mathrm{PD}-1^{+}$immune subset, and not the CD8 ${ }^{-} \mathrm{PD}-1^{+}$immune subset, that offered prognostic value. Further studies to stratify the CD8 $8^{-} \mathrm{PD}-1^{+}$immune subsets in TNBC even further are warranted to characterize the immune microenvironment of TNBC. For example, are these primarily natural killer cells, $\mathrm{CD} 4^{+}$effector $\mathrm{T}$ cells, or regulatory $\mathrm{T}$ cells?

Clinical management options for TNBC remain limited, despite relatively high TIL numbers [16-18], PD-L1 expression [19-21] and tumor mutational burden [22, 23] compared with other subtypes, and multiple clinical trials have focused on targeting TNBC [16, 20, 22, 23, 121-124]. However, the outcome either remains sub-optimal or with conclusions still pending, regardless of which PD-1/PD-L1 monoclonal antibodies are used [7-15]. Our study may provide further insight to this field, as the results revealed that high expression of PD-1/PD-L1 pathways in TNBC was significantly associated with improved clinical outcomes. This suggests that the immune microenvironment in TNBC may not be as suppressed as in other tumors, such as non-small-cell lung carcinoma, melanoma and bladder cancer.

In conclusion, our study demonstrated that PD- $1^{+}$immune infiltrates, PD-L1 tumor cell expression and the expression of relevant genes are positively associated with an improved clinical outcome in TNBC. Furthermore, the prognostic values were independent of clinicopathological parameters. The mRNA levels of PDCD1, CD274 and IFNG also represent measurable molecular prognostic markers. The function of the PD-1/PD-L1 pathway in the TNBC tumor immune microenvironment warrants further study, and may potentially provide alternative, effective novel targets for breast cancer immunotherapy in the near future. Finally, this may also help inform which combinations of strategies are most appropriate $[125,126]$.

\section{Additional file}

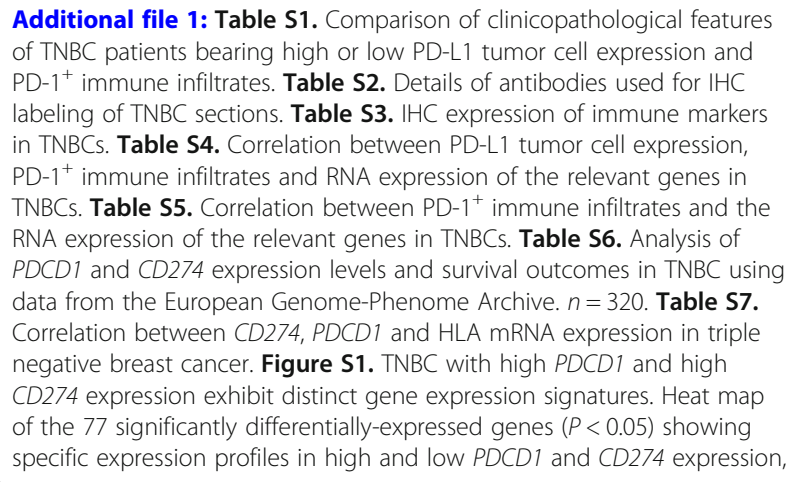

clustered using Euclidean distances on the $z$ scores computed from the $\log 10$ transformed counts. The heat map is colored using z scores with the highest expression in yellow and the lowest expression in blue. PDCD1 (encoding PD-1), CD274 (encoding PD-L1). Figure S2. TNBC with both high PDCD1 and high CD274 expression show a trend for improved survival in a public dataset from TCGA. From publicly available TNBC dataset from TCGA, Kaplan-Meier analysis of OS outcomes in women with high PDCD1 and high CD274 expression compared with the rest of the cases in the cohort $(n=89)$. TNBC, Triple negative breast cancer; TCGA, The Cancer Genome Atlas. The trend is observed but the statistical significance is not achieved probably due to the small sample size in this public dataset. Figure S3. Flow cytometry analysis demonstrated the correlation between PD-L1 and MHC-I on multiple human TNBC cell lines. PDL1, programmed cell death ligand 1; MHC-I, major histocompatibility complex class I (HLAABC). Figure S4. Expression levels of a panel of 5 genes from IFN signaling define two groups of TNBC patients. Unsupervised hierarchical clustering using Euclidean distance revealed the existence of two TNBC patient clusters (red and green) based on expression intensity of the 5 genes listed. The heat map is colored by the log10 normalized counts with the highest expression in red and the lowest expression in blue. Figure S5. Scoring of PD- $1^{+}$immune infiltrates data on TMA can be validated with whole section scoring. (A) Manual scoring on whole slide sections shows that TNBCs bearing high $\mathrm{PD}-1^{+}$immune infiltrates (tissue microarray analyses) harbored significantly higher PD $-1^{+}$immune infiltrates. (B) Manual scoring on whole slide sections shows significant correlation with the scoring done on tissue microarray. (DOCX $413 \mathrm{~kb}$ )

\section{Acknowledgements}

Not applicable

\section{Funding}

This research was funded by the A*STAR Biomedical Research Council, National Medical Research Council Stratified Medicine Programme Office (SMPO201302) awarded to Dr. Puay Hoon Tan, and partially supported by the SingHealth Duke-NUS Pathology Academic Clinical Program Budding Clinician-Scientist grant (ACP PATH BCS 14 001) awarded to Dr.

Timothy Kwang Yong Tay. Dr. Jabed labal is a recipient of the Transition Award from the Singapore National Medical Research Council (NMRC/TA/ 0041/2015)

\section{Availability of data and materials}

The datasets used and/or analysed during the current study are available from the corresponding author on reasonable request.

\section{Authors' contributions}

The study was designed and directed by RD, EWN and PHT, and coordinated by JY. JY, JCTL, AAT, CCHO, WHY, AYHL, SW and II acquired the data. The analysis was done by $B L, H L, Y Y, J L$ and JC. TTKY, Jl and PHT provided advice from pathology perspectives. EHL and RD provided advice from clinical perspectives. SW and EWN provided advice from immunology perspectives JY, $\mathrm{RD}, \mathrm{EWN}$ and PHT drafted the manuscript, which was commented on and revised by all authors. All authors read and approved the final manuscript.

Ethics approval and consent to participate

The Centralized Institutional Review Board of SingHealth provided ethical approval for the use of patient materials in this study (CIRB ref.: 2013/664/F and 2015/2199)

\section{Consent for publication}

Not applicable.

\section{Competing interests}

The authors declare that they have no competing interests.

\section{Publisher's Note}

Springer Nature remains neutral with regard to jurisdictional claims in published maps and institutional affiliations. 


\section{Author details}

'Division of Pathology, Singapore General Hospital, 20 College Road, Academia, Level 7, Singapore 169856, Singapore. ${ }^{2}$ Singapore Immunology Network (SlgN), Agency of Science, Technology and Research (A*STAR), 8A, Biomedical Grove, Immunos, Singapore 138648, Singapore. ${ }^{3}$ Division of Medicine, Singapore General Hospital, Singapore, Singapore. ${ }^{4}$ Duke-NUS Medical School, Singapore, Singapore. ${ }^{5}$ Centre for Quantitative Medicine, Duke-NUS Medical School, Singapore, Singapore. ${ }^{6}$ Shanghai University of Finance and Economics, Shanghai, China. 'Yong Loo Lin School of Medicine, National University of Singapore, Singapore, Singapore. ${ }^{8}$ National Cancer Centre Singapore, 11 Hospital Drive, Singapore 169610, Singapore.

Received: 19 July 2018 Accepted: 7 January 2019 Published online: 06 February 2019

\section{References}

1. Thike AA, Cheok PY, Jara-Lazaro AR, Tan B, Tan P, Tan PH. Triple-negative breast cancer: clinicopathological characteristics and relationship with basallike breast cancer. Mod Pathol. 2009;23(1):123-33.

2. labal J, Ginsburg O, Rochon PA, Sun P, Narod SA. Dlfferences in breast cancer stage at diagnosis and cancer-specific survival by race and ethnicity in the United States. JAMA. 2015;313(2):165-73.

3. Foulkes WD, Smith IE, Reis-Filho JS. Triple-negative breast Cancer. New Engl J Med. 2010:363(20):1938-48.

4. Dent R, Trudeau M, Pritchard Kl, Hanna WM, Kahn HK, Sawka CA, et al. Triple-negative breast cancer: clinical features and patterns of recurrence. Clin Cancer Res. 2007;13(15 Pt 1):4429-34

5. Kassam F, Enright K, Dent R, Dranitsaris G, Myers J, Flynn C, et al. Survival outcomes for patients with metastatic triple-negative breast cancer: implications for clinical practice and trial design. Clin Breast Cancer. 2009; 9(1):29-33.

6. Thike AA, Yong-Zheng Chong L, Cheok PY, Li HH, Wai-Cheong Yip G, Huat Bay $B$, et al. Loss of androgen receptor expression predicts early recurrence in triple-negative and basal-like breast cancer. Mod Pathol. 2014;27(3):352-60.

7. Hartkopf AD, Taran F-A, Wallwiener M, Walter CB, Krämer B, Grischke E-M, et al. PD-1 and PD-L1 immune checkpoint blockade to treat breast Cancer. Breast Care. 2016;11(6):385-90.

8. Schütz F, Stefanovic S, Mayer L, von Au A, Domschke C, Sohn C. PD-1/PD-L1 pathway in breast Cancer. Oncol Res Treat. 2017:40(5):294-7.

9. Bertucci F, Gonçalves A. Immunotherapy in breast Cancer: the emerging role of PD-1 and PD-L1. Curr Oncol Rep. 2017;19(10):64.

10. Nanda R, Chow LQ, Dees EC, Berger R, Gupta S, Geva R, et al. Pembrolizumab in patients with advanced triple-negative breast Cancer: phase Ib KEYNOTE-012 study. J Clin Oncol. 2016;34(21):2460-7.

11. Adams S, Schmid P, Rugo HS, Winer EP, Loirat D, Awada A, et al. Phase 2 study of pembrolizumab (pembro) monotherapy for previously treated metastatic triple-negative breast cancer (mTNBC): KEYNOTE-086 cohort a. J Clin Oncol. 2017;35(15_suppl):1008.

12. Schmid P, Park YH, Muñoz-Couselo E, Kim S-B, Sohn J, Im S-A, et al. Pembrolizumab (pembro) + chemotherapy (chemo) as neoadjuvant treatment for triple negative breast cancer (TNBC): preliminary results from KEYNOTE-173. J Clin Oncol. 2017:35(15 suppl):556.

13. Loibl S, Untch M, Burchardi N, Huober JB, Blohmer JU, Grischke E-M, et al. A randomized phase II neoadjuvant study (GeparNuevo) to investigate the addition of durvalumab, a PD-L1 antibody, to a taxane-anthracycline containing chemotherapy in triple negative breast cancer (TNBC). J Clin Oncol. 2017;35(15_suppl):3062.

14. Adams S, Diamond JR, Hamilton EP, Pohlmann PR, Tolaney SM, Molinero L, et al. Phase Ib trial of atezolizumab in combination with nab-paclitaxel in patients with metastatic triple-negative breast cancer (mTNBC). J Clin Oncol. 2016;34(15_suppl):1009.

15. Dirix LY, Takacs I, Jerusalem G, Nikolinakos P, Arkenau HT, Forero-Torres A, et al. Avelumab, an anti-PD-L1 antibody, in patients with locally advanced or metastatic breast cancer: a phase 1b JAVELIN solid tumor study. Breast Cancer Res Treat. 2017:23(10):017-4537.

16. Denkert C, von Minckwitz G, Brase JC, Sinn BV, Gade S, Kronenwett R, et al. Tumor-infiltrating lymphocytes and response to neoadjuvant chemotherapy with or without carboplatin in human epidermal growth factor receptor 2positive and triple-negative primary breast cancers. J Clin Oncol. 2015;33(9): 983-91.
17. Loi S, Sirtaine N, Piette F, Salgado R, Viale G, Van Eenoo F, et al. Prognostic and predictive value of tumor-infiltrating lymphocytes in a phase III randomized adjuvant breast cancer trial in node-positive breast cancer comparing the addition of docetaxel to doxorubicin with doxorubicinbased chemotherapy: BIG 02-98. J Clin Oncol. 2013;31(7):860-7.

18. Adams S, Gray RJ, Demaria S, Goldstein L, Perez EA, Shulman LN, et al. Prognostic value of tumor-infiltrating lymphocytes in triple-negative breast cancers from two phase III randomized adjuvant breast Cancer trials: ECOG 2197 and ECOG 1199. J Clin Oncol. 2014:32(27):2959-66.

19. Mittendorf EA, Philips AV, Meric-Bernstam F, Qiao N, Wu Y, Harrington S, et al. PD-L1 expression in triple-negative breast cancer. Cancer Immunol Res. 2014;2(4):361-70.

20. Ghebeh H, Mohammed S, Al-Omair A, Qattan A, Lehe C, Al-Qudaihi G, et al. The B7-H1 (PD-L1) T lymphocyte-inhibitory molecule is expressed in breast cancer patients with infiltrating ductal carcinoma: correlation with important high-risk prognostic factors. Neoplasia. 2006;8(3):190-8.

21. Zhang M, Sun H, Zhao S, Wang Y, Pu H, Zhang Q. Expression of PD-L1 and prognosis in breast cancer: a meta-analysis. Oncotarget. 2017;8(19):31347-54.

22. Comprehensive molecular portraits of human breast tumours. Nature. 2012; 490(7418):61-70

23. Shah SP, Roth A, Goya R, Oloumi A, Ha G, Zhao Y, et al. The clonal and mutational evolution spectrum of primary triple-negative breast cancers. Nature. 2012:486(7403):395-9.

24. Hainaut $P$, Plymoth $A$. Targeting the hallmarks of cancer: towards a rational approach to next-generation cancer therapy. Curr Opin Oncol. 2013;25(1):50-1.

25. Hanahan D, Weinberg RA. Hallmarks of cancer: the next generation. Cell. 2011;144(5):646-74.

26. Dunn GP, Old $L$, Schreiber RD. The three Es of cancer immunoediting. Annu Rev Immunol. 2004;22:329-60.

27. Mittal D, Gubin MM, Schreiber RD, Smyth MJ. New insights into cancer immunoediting and its three component phases — elimination, equilibrium and escape. Curr Opin Immunol. 2014;27:16-25.

28. Stagg J, Allard B. Immunotherapeutic approaches in triple-negative breast cancer: latest research and clinical prospects. Ther Adv Med Oncol. 2013: 5(3):169-81

29. Anders CK, Deal AM, Miller CR, Khorram C, Meng H, Burrows E, et al. The prognostic contribution of clinical breast cancer subtype, age, and race among patients with breast cancer brain metastases. Cancer. 2011;117(8):1602-11.

30. Bottai G, Raschioni C, Losurdo A, Di Tommaso L, Tinterri C, Torrisi R, et al. An immune stratification reveals a subset of PD-1/LAG-3 double-positive triplenegative breast cancers. Breast Cancer Res. 2016;18(1):121.

31. Zarour HM. Reversing T-cell dysfunction and exhaustion in Cancer. Clin Cancer Res. 2016:22(8):1856-64.

32. Bi J, Tian Z. NK cell exhaustion. Front Immunol. 2017;8:760.

33. Beldi-Ferchiou A, Lambert M, Dogniaux S, Vély F, Vivier E, Olive D, et al. PD1 mediates functional exhaustion of activated NK cells in patients with Kaposi sarcoma. Oncotarget. 2016:7(45):72961-77.

34. Liu Y, Cheng Y, Xu Y, Wang Z, Du X, Li C, et al. Increased expression of programmed cell death protein 1 on NK cells inhibits NK-cell-mediated antitumor function and indicates poor prognosis in digestive cancers. Oncogene. 2017;36:6143.

35. Pauken KE, Wherry EJ. SnapShot: T cell exhaustion. Cell. 2015;163(4):1038-.e1.

36. Wherry EJ, Kurachi M. Molecular and cellular insights into T cell exhaustion. Nat Rev Immunol. 2015;15(8):486-99.

37. Jiang Y, Li Y, Zhu B. T-cell exhaustion in the tumor microenvironment. Cell Death Dis. 2015;6:e1792

38. Gordon SR, Maute RL, Dulken BW, Hutter G, George BM, McCracken MN, et al. PD-1 expression by tumour-associated macrophages inhibits phagocytosis and tumour immunity. Nature. 2017:545:495.

39. Park IH, Yang HN, Lee KJ, Kim TS, Lee ES, Jung SY, et al. Tumor-derived IL-18 induces PD-1 expression on immunosuppressive NK cells in triple-negative breast cancer. Oncotarget. 2017:8(20):32722-30. https://doi.org/10.18632/ oncotarget.6281.

40. Jin S, Xu B, Yu L, Fu Y, Wu H, Fan X, et al. The PD-1, PD-L1 expression and $\mathrm{CD} 3+\mathrm{T}$ cell infiltration in relation to outcome in advanced gastric signetring cell carcinoma, representing a potential biomarker for immunotherapy. J Clin Oncol. 2017;35(15_suppl):e15609-e.

41. Golden-Mason L, Palmer B, Klarquist J, Mengshol JA, Castelblanco N, Rosen HR. Upregulation of PD-1 expression on circulating and intrahepatic hepatitis C virus-specific CD8(+) T cells associated with reversible immune dysfunction. J Virol. 2007:81(17):9249-58. 
42. Kansy BA, Concha-Benavente F, Srivastava RM, Jie HB, Shayan G, Lei Y, et al. PD-1 status in CD8+ T cells associates with survival and anti-PD-1 therapeutic outcomes in head and neck cancer. Cancer Res. 2017;77(22): 6353-64.

43. Ahmadzadeh M, Johnson LA, Heemskerk B, Wunderlich JR, Dudley ME, White DE, et al. Tumor antigen-specific CD8 T cells infiltrating the tumor express high levels of PD-1 and are functionally impaired. Blood. 2009; 114(8):1537-44.

44. Shen $T$, Zhou L, Shen $H$, Shi C, Jia S, Ding GP, et al. Prognostic value of programmed cell death protein 1 expression on CD8+ T lymphocytes in pancreatic cancer. Sci Rep. 2017;7(1):7848

45. Garnelo M, Tan A, Her Z, Yeong J, Lim CJ, Chen J, et al. Interaction between tumour-infiltrating $B$ cells and $T$ cells controls the progression of hepatocellular carcinoma. Gut. 2015;15(310814):2015-310814.

46. Egelston C, Avalos C, Lee PP. PD-1 expression is not indicative of T cell exhaustion in breast cancer tumors. J Immunol. 2016;196(1 Supplement):72.18.

47. Lakhani S, Ellis I, Schnitt S, Tan P, Van de Vijver M. World Health Organisation classification of tumors of the breast. Int Agency Res Cancer. 2012;4:142-7.

48. Thike AA, lqbal J, Cheok PY, Tse GM, Tan PH. Ductal carcinoma in situ associated with triple negative invasive breast cancer: evidence for a precursor-product relationship. J Clin Pathol. 2013;66(8):665-70.

49. Wolff AC, Hammond ME, Hicks DG, Dowsett M, McShane LM, Allison KH, et al. Recommendations for human epidermal growth factor receptor 2 testing in breast cancer: American Society of Clinical Oncology/College of American Pathologists clinical practice guideline update. J Clin Oncol. 2013; 31(31):3997-4013.

50. Fan YS, Casas CE, Peng J, Watkins M, Fan L, Chapman J, et al. HER2 FISH classification of equivocal HER2 IHC breast cancers with use of the 2013 ASCO/CAP practice guideline. Breast Cancer Res Treat. 2016; 155(3):457-62

51. Wolff AC, Hammond ME, Hicks DG, Dowsett M, McShane LM, Allison KH, et al. Recommendations for human epidermal growth factor receptor 2 testing in breast cancer: American Society of Clinical Oncology/College of American Pathologists clinical practice guideline update. Arch Pathol Lab Med. 2014:138(2):241-56

52. Reck M, Rodríguez-Abreu D, Robinson AG, Hui R, Csőszi T, Fülöp A, et al. Pembrolizumab versus chemotherapy for PD-L1-positive non-small-cell lung Cancer. New Engl J Med. 2016;375(19):1823-33.

53. Borghaei $H$, Paz-Ares $L$, Horn $L$, Spigel DR, Steins $M$, Ready NE, et al. Nivolumab versus docetaxel in advanced nonsquamous non-small-cell lung Cancer. N Engl J Med. 2015:373(17):1627-39.

54. Sun WY, Lee YK, Koo JS. Expression of PD-L1 in triple-negative breast cancer based on different immunohistochemical antibodies. J Transl Med. 2016:14:173.

55. Beckers RK, Selinger Cl, Vilain R, Madore J, Wilmott JS, Harvey K, et al. Programmed death ligand 1 expression in triple-negative breast cancer is associated with tumour-infiltrating lymphocytes and improved outcome. Histopathology. 2016;69(1):25-34

56. Kim JR, Moon YJ, Kwon KS, Bae JS, Wagle S, Kim KM, et al. Tumor infiltrating PD1-positive lymphocytes and the expression of PD-L1 predict poor prognosis of soft tissue sarcomas. PLoS One. 2013:8(12):e82870.

57. Kang MJ, Kim KM, Bae JS, Park HS, Lee H, Chung MJ, et al. Tumor-infiltrating PD1-positive lymphocytes and FoxP3-positive regulatory $T$ cells predict distant metastatic relapse and survival of clear cell renal cell carcinoma. Transl Oncol. 2013;6(3):282-9.

58. Cao J, Brouwer NJ, Richards KE, Marinkovic M, van Duinen S, Hurkmans D, et al. PD-L1/PD-1 expression and tumor-infiltrating lymphocytes in conjunctival melanoma. Oncotarget. 2017:8(33):54722-34.

59. Yeong J, Thike AA, Ikeda M, Lim JCT, Lee B, Nakamura S, et al. Caveolin-1 expression as a prognostic marker in triple negative breast cancers of Asian women. J Clin Pathol. 2018;71(2):161-7.

60. Matsumoto $H$, Thike AA, Li H, Yeong J, Koo SL, Dent RA, et al. Increased CD4 and CD8-positive T cell infiltrate signifies good prognosis in a subset of triple-negative breast cancer. Breast Cancer Res Treat. 2016;156(2):237-47.

61. Yeong J, Lim JCT, Lee B, Li H, Chia N, Ong CCH, et al. High densities of tumor-associated plasma cells predict improved prognosis in triple negative breast Cancer. Frontiers Immunol. 2018;9:1209.

62. Stack EC, Wang C, Roman KA, Hoyt CC. Multiplexed immunohistochemistry, imaging, and quantitation: a review, with an assessment of Tyramide signal amplification, multispectral imaging and multiplex analysis. Methods. 2014; 70(1):46-58
63. Abel EJ, Bauman TM, Weiker M, Shi F, Downs TM, Jarrard DF, et al. Analysis and validation of tissue biomarkers for renal cell carcinoma using automated high-throughput evaluation of protein expression. Hum Pathol. 2014:45(5):1092-9.

64. Lovisa S, LeBleu VS, Tampe B, Sugimoto H, Vadnagara K, Carstens JL, et al. Epithelial-to-mesenchymal transition induces cell cycle arrest and parenchymal damage in renal fibrosis. Nat Med. 2015;21(9):998-1009.

65. Garnelo M, Tan A, Her Z, Yeong J, Lim CJ, Chen J, et al. Interaction between tumour-infiltrating B cells and T cells controls the progression of hepatocellular carcinoma. Gut. 2017;66(2):342-51.

66. Lim JCT, Yeong JPS, Lim CJ, Ong CCH, Chew VSP, Ahmed SS, Tan PH, Iqbal J. An automated staining protocol for 7-colour immunofluorescence of human tissue sections for diagnostic and prognostic use. Pathology. 2018; 50(3):333-41.

67. Esbona K, Inman D, Saha S, Jeffery J, Schedin P, Wilke L, et al. COX-2 modulates mammary tumor progression in response to collagen density. Breast Cancer Res. 2016;18(1):35.

68. Mlecnik B, Bindea G, Kirilovsky A, Angell HK, Obenauf AC, Tosolini M, et al. The tumor microenvironment and immunoscore are critical determinants of dissemination to distant metastasis. Sci Transl Med. 2016;8(327):327ra26.

69. Nghiem PT, Bhatia S, Lipson EJ, Kudchadkar RR, Miller NJ, Annamalai L, et al. PD-1 blockade with Pembrolizumab in advanced Merkel-cell carcinoma. New Engl J Med. 2016;374(26):2542-52.

70. Feng Z, Jensen SM, Messenheimer DJ, Farhad M, Neuberger M, Bifulco CB et al. Multispectral imaging of $T$ and $B$ cells in murine spleen and tumor. J Immunol. 2016;196(9):3943-50.

71. Yeong J, Thike AA, Lim JC, Lee B, Li H, Wong SC, et al. Higher densities of Foxp3+ regulatory $T$ cells are associated with better prognosis in triplenegative breast cancer. Breast Cancer Res Treat. 2017;23(10):017-4161.

72. Fiore C, Bailey D, Conlon N, Wu X, Martin N, Fiorentino M, et al. Utility of multispectral imaging in automated quantitative scoring of immunohistochemistry. J Clin Pathol. 2012;65(6):496-502.

73. Feng Z, Bethmann D, Kappler M, Ballesteros-Merino C, Eckert A, Bell RB, et al. Multiparametric immune profiling in HPV- oral squamous cell cancer. JCl Insight. 2017;2(14):e93652.

74. Rosen PP. Tumor emboli in intramammary lymphatics in breast carcinoma: pathologic criteria for diagnosis and clinical significance. Pathol Annu. 1983; 18(Pt 2):215-32.

75. Ejlertsen B, Jensen MB, Rank F, Rasmussen BB, Christiansen P, Kroman N, et al. Population-based study of peritumoral lymphovascular invasion and outcome among patients with operable breast cancer. J Natl Cancer Inst. 2009;101(10):729-35.

76. Geiss GK, Bumgarner RE, Birditt B, Dahl T, Dowidar N, Dunaway DL, et al. Direct multiplexed measurement of gene expression with color-coded probe pairs. Nat Biotechnol. 2008:26(3):317-25.

77. Felsenstein KM, Saunders LB, Simmons JK, Leon E, Calabrese DR, Zhang S, et al. Small molecule microarrays enable the identification of a selective, Quadruplex-binding inhibitor of MYC expression. ACS Chem Biol. 2016;11(1): 139-48.

78. Pardoll DM. The blockade of immune checkpoints in cancer immunotherapy. Nat Rev Cancer. 2012;12(4):252-64.

79. Rody A, Holtrich U, Pusztai L, Liedtke C, Gaetje R, Ruckhaeberle E, et al. T-cell metagene predicts a favorable prognosis in estrogen receptor-negative and HER2-positive breast cancers. Breast Cancer Res. 2009;11(2):R15

80. Nagalla S, Chou JW, Willingham MC, Ruiz J, Vaughn JP, Dubey P, et al. Interactions between immunity, proliferation and molecular subtype in breast cancer prognosis. Genome Biol. 2013;14(4):R34.

81. Kuo WH, Chang YY, Lai LC, Tsai MH, Hsiao CK, Chang K, et al. Molecular characteristics and metastasis predictor genes of triple-negative breast cancer: a clinical study of triple-negative breast carcinomas. PLoS One. 2012;7(9):25.

82. Balko JM, Giltnane JM, Wang K, Schwarz LJ, Young CD, Cook RS, et al. Molecular profiling of the residual disease of triple-negative breast cancers after neoadjuvant chemotherapy identifies actionable therapeutic targets. Cancer Discov. 2014:4(2):232-45.

83. Bhola NE, Balko JM, Dugger TC, Kuba MG, Sanchez V, Sanders M, et al. TGFbeta inhibition enhances chemotherapy action against triple-negative breast cancer. J Clin Invest. 2013;123(3):1348-58.

84. Balko JM, Cook RS, Vaught DB, Kuba MG, Miller TW, Bhola NE, et al. Profiling of residual breast cancers after neoadjuvant chemotherapy identifies DUSP4 deficiency as a mechanism of drug resistance. Nat Med. 2012;18(7):1052-9. 
85. Pereira B, Chin SF, Rueda OM, Vollan HK, Provenzano E, Bardwell HA, et al. The somatic mutation profiles of 2,433 breast cancers refines their genomic and transcriptomic landscapes. Nat Commun. 2016;7:11479.

86. Gao J, Aksoy BA, Dogrusoz U, Dresdner G, Gross B, Sumer SO, et al. Integrative analysis of complex cancer genomics and clinical profiles using the cBioPortal. Sci Signal. 2013;6(269):pl1.

87. Cerami E, Gao J, Dogrusoz U, Gross BE, Sumer SO, Aksoy BA, et al. The cBio cancer genomics portal: an open platform for exploring multidimensional cancer genomics data. Cancer Discov. 2012;2(5):401-4.

88. Kim JM, Chen DS. Immune escape to PD-L1/PD-1 blockade: seven steps to success (or failure). Ann Oncol. 2016;27(8):1492-504.

89. Aust S, Felix S, Auer K, Bachmayr-Heyda A, Kenner L, Dekan S, et al. Absence of PD-L1 on tumor cells is associated with reduced $\mathrm{MHC}$ I expression and PD-L1 expression increases in recurrent serous ovarian cancer. Sci Rep. 2017; 7:42929.

90. Garcia-Lora A, Algarra I, Garrido F. MHC class I antigens, immune surveillance, and tumor immune escape. J Cell Physiol. 2003;195(3):346-55.

91. Garrido F, Aptsiauri N, Doorduijn EM, Garcia Lora AM, van Hall T. The urgent need to recover $\mathrm{MHC}$ class I in cancers for effective immunotherapy. Curr Opin Immunol. 2016;39:44-51.

92. Ikeda $\mathrm{H}$, Old $\mathrm{L}$, Schreiber $\mathrm{RD}$. The roles of IFN gamma in protection against tumor development and cancer immunoediting. Cytokine Growth Factor Rev. 2002;13(2):95-109.

93. Dunn GP, Ikeda H, Bruce AT, Koebel C, Uppaluri R, Bui J, et al. Interferongamma and cancer immunoediting. Immunol Res. 2005;32(1-3):231-45.

94. Dunn GP, Bruce AT, Ikeda H, Old L, Schreiber RD. Cancer immunoediting: from immunosurveillance to tumor escape. Nat Immunol. 2002;3(11):991-8.

95. Ayers M, Lunceford J, Nebozhyn M, Murphy E, Loboda A, Kaufman DR, et al. IFN- $\gamma$-related mRNA profile predicts clinical response to PD-1 blockade. J Clin Invest. 2017;127(8):2930-40.

96. Botti G, Collina F, Scognamiglio G, Rao F, Peluso V, De Cecio R, et al. Programmed death ligand 1 (PD-L1) tumor expression is associated with a better prognosis and diabetic disease in triple negative breast Cancer patients. Int J Mol Sci. 2017:18(2):E459.

97. Li X, Wetherilt CS, Krishnamurti U, Yang J, Ma Y, Styblo TM, et al. Stromal PD-L1 expression is associated with better disease-free survival in triplenegative breast Cancer. Am J Clin Pathol. 2016;146(4):496-502.

98. Guo L, Li W, Zhu X, Ling Y, Qiu T, Dong L, et al. PD-L1 expression and $C D 274$ gene alteration in triple-negative breast cancer: implication for prognostic biomarker. Springerplus. 2016;5(1):805.

99. Mori H, Kubo M, Yamaguchi R, Nishimura R, Osako T, Arima N, et al. The combination of PD-L1 expression and decreased tumor-infiltrating lymphocytes is associated with a poor prognosis in triple-negative breast cancer. Oncotarget. 2017:8(9):15584-92.

100. Wang C, Zhu H, Zhou Y, Mao F, Lin Y, Pan B, et al. Prognostic value of PDL1 in breast Cancer: a meta-analysis. Breast J. 2017;23(4):436-43.

101. Tsang JY, Au WL, Lo KY, Ni YB, Hlaing T, Hu J, et al. PD-L1 expression and tumor infiltrating PD-1+ lymphocytes associated with outcome in HER2+ breast cancer patients. Breast Cancer Res Treat. 2017;162(1):19-30.

102. Buisseret L, Garaud S, de Wind A, Van den Eynden G, Boisson A, Solinas C, et al. Tumor-infiltrating lymphocyte composition, organization and PD-1/ PD-L1 expression are linked in breast cancer. Oncoimmunology. 2017;6(1): e1257452

103. Baptista MZ, Sarian LO, Derchain SF, Pinto GA, Vassallo J. Prognostic significance of PD-L1 and PD-L2 in breast cancer. Hum Pathol. 2016;47(1): 78-84.

104. Wimberly H, Brown JR, Schalper K, Haack H, Silver MR, Nixon C, et al. PD-L1 expression correlates with tumor-infiltrating lymphocytes and response to neoadjuvant chemotherapy in breast Cancer. Cancer Immunol Res. 2015: 3(4):326-32.

105. Dill EA, Gru AA, Atkins KA, Friedman LA, Moore ME, Bullock TN, et al. PD-L1 expression and Intratumoral heterogeneity across breast Cancer subtypes and stages: an assessment of 245 primary and 40 metastatic tumors. Am J Surg Pathol. 2017:41(3):334-42.

106. Chen S, Wang RX, Liu Y, Yang WT, Shao ZM. PD-L1 expression of the residual tumor serves as a prognostic marker in local advanced breast cancer after neoadjuvant chemotherapy. Int J Cancer. 2017;140(6):1384-95

107. Li Z, Dong P, Ren M, Song Y, Qian X, Yang Y, et al. PD-L1 expression is associated with tumor FOXP3(+) regulatory T-cell infiltration of breast Cancer and poor prognosis of patient. J Cancer. 2016;7(7):784-93.
108. Qin T, Zeng YD, Qin G, Xu F, Lu JB, Fang WF, et al. High PD-L1 expression was associated with poor prognosis in 870 Chinese patients with breast cancer. Oncotarget. 2015;6(32):33972-81.

109. Simon S, Labarriere N. PD-1 expression on tumor-specific T cells: friend or foe for immunotherapy? Oncoimmunology. 2018;7(1):e1364828.

110. Inozume T, Hanada K, Wang QJ, Ahmadzadeh M, Wunderlich JR, Rosenberg SA, et al. Selection of CD8+PD-1+ lymphocytes in fresh human melanomas enriches for tumor-reactive T cells. J Immunother. 2010;33(9):956-64.

111. Gros A, Robbins PF, Yao X, Li YF, Turcotte S, Tran E, et al. PD-1 identifies the patient-specific CD8(+) tumor-reactive repertoire infiltrating human tumors. J Clin Invest. 2014;124(5):2246-59.

112. Simon S, Vignard V, Florenceau L, Dreno B, Khammari A, Lang F, et al. PD-1 expression conditions $T$ cell avidity within an antigen-specific repertoire. Oncoimmunology. 2016;5(1):e1104448.

113. Chauvin JM, Pagliano O, Fourcade J, Sun Z, Wang H, Sander C, et al. TIGIT and PD-1 impair tumor antigen-specific CD8(+) T cells in melanoma patients. J Clin Invest. 2015;125(5):2046-58.

114. Gupta PK, Godec J, Wolski D, Adland E, Yates K, Pauken KE, et al. CD39 expression identifies terminally exhausted CD8+ T cells. PLoS Pathog. 2015; 11(10):e1005177.

115. Canale FP, Ramello MC, Nunez N, Furlan CLA, Bossio SN, Serran MG, et al. CD39 expression defines cell exhaustion in tumor-infiltrating CD8(+) T cells. Cancer Res. 2018;78(1):115-28.

116. Simoni Y, Becht E, Fehlings M, Loh CY, Koo S-L, Teng KWW, et al. Bystander CD8+ T cells are abundant and phenotypically distinct in human tumour infiltrates. Nature. 2018:557(7706):575-9.

117. Paley MA, Kroy DC, Odorizzi PM, Johnnidis JB, Dolfi DV, Barnett BE, et al. Progenitor and terminal subsets of CD8(+) T cells cooperate to contain chronic viral infection. Science (New York, NY). 2012;338(6111):1220-5.

118. Odorizzi PM, Pauken KE, Paley MA, Sharpe A, Wherry EJ. Genetic absence of PD-1 promotes accumulation of terminally differentiated exhausted CD8<sup $>+</$ sup $>$ T cells. J Exp Med. 2015;212(7):1125-37.

119. Banerjee A, Gordon SM, Intlekofer AM, Paley MA, Mooney EC, Lindsten T, et al. Cutting edge: the transcription factor eomesodermin enables CD8+ T cells to compete for the memory cell niche. J Immunol. 2010;185(9):4988-92.

120. Buggert M, Tauriainen J, Yamamoto T, Frederiksen J, Ivarsson MA, Michaëlsson J, et al. T-bet and Eomes are differentially linked to the exhausted phenotype of CD8+ T cells in HIV infection. PLoS Pathog. 2014; 10(7):e1004251.

121. Bates GJ, Fox SB, Han C, Leek RD, Garcia JF, Harris AL, et al. Quantification of regulatory $T$ cells enables the identification of high-risk breast cancer patients and those at risk of late relapse. J Clin Oncol. 2006;24(34):5373-80.

122. Liu S, Lachapelle J, Leung S, Gao D, Foulkes WD, Nielsen TO. CD8+ lymphocyte infiltration is an independent favorable prognostic indicator in basal-like breast cancer. Breast Cancer Res. 2012;14(2):R48.

123. Liyanage UK, Moore $\Pi$, Joo HG, Tanaka Y, Herrmann V, Doherty G, et al. Prevalence of regulatory $T$ cells is increased in peripheral blood and tumor microenvironment of patients with pancreas or breast adenocarcinoma. J Immunol. 2002;169(5):2756-61.

124. Saal LH, Holm K, Maurer M, Memeo L, Su T, Wang X, et al. PIK3CA mutations correlate with hormone receptors, node metastasis, and ERBB2, and are mutually exclusive with PTEN loss in human breast carcinoma. Cancer Res. 2005;65(7):2554-9.

125. Tan TJ, Chan JJ, Kamis S, Dent RA. What is the role of immunotherapy in breast cancer. Chin Clin Oncol. 2018;7(2):13.

126. Telli ML, Stover DG. Homologous recombination deficiency and host antitumor immunity in triple-negative breast cancer; 2018.

Ready to submit your research? Choose BMC and benefit from:

- fast, convenient online submission

- thorough peer review by experienced researchers in your field

- rapid publication on acceptance

- support for research data, including large and complex data types

- gold Open Access which fosters wider collaboration and increased citations

- maximum visibility for your research: over $100 \mathrm{M}$ website views per year

At $\mathrm{BMC}$, research is always in progress.

Learn more biomedcentral.com/submission 